Article

\title{
Optimal Nitrogen Practice in Winter Wheat-Summer Maize Rotation Affecting the Fates of ${ }^{15} \mathrm{~N}$-Labeled Fertilizer
}

\author{
Haiyan Liang, Pengfei Shen, Xiangze Kong, Yuncheng Liao, Yang Liu * and Xiaoxia Wen * \\ College of Agronomy, Northwest A\&F University, Yangling 712100, Shaanxi, China; \\ 15094073735@163.com (H.L.); spf429537023@163.com (P.S.); kongxiangze25@163.com (X.K.); \\ yunchengliao@163.com (Y.L.) \\ * Correspondence: yangl@nwafu.edu.cn (Y.L.); wenxiaoxia6811@163.com (X.W.)
}

Received: 11 February 2020; Accepted: 27 March 2020; Published: 6 April 2020

\begin{abstract}
Lower nitrogen recovery efficiency (NRE) and negative environmental impacts caused by excessive nitrogen $(\mathrm{N})$ fertilization threaten the sustainability of agriculture. Efficient and appropriate fertilization practices are extremely important to achieve higher crop yield with minimum $\mathrm{N}$ loss. A field microplot experiment was conducted in a wheat-maize rotation system in Shaanxi province, at North China Plain, using the ${ }^{15} \mathrm{~N}$ isotope tracer technique to qualify the different annual $\mathrm{N}$ managements in terms of crop yield, NRE, $\mathrm{N}$ distribution in plant-soil, and $\mathrm{N}$ losses to optimize the $\mathrm{N}$ management. The experiment included four $\mathrm{N}$ treatments: conventional practice with $510 \mathrm{~kg} \mathrm{ha}^{-1}$ annually in four applications (N1), and three optimized N treatments, reducing $\mathrm{N}$ rate to $420 \mathrm{~kg} \mathrm{ha}^{-1}$, adjusting topdressing fertilizer times and using slow-release fertilizer (SRF) (N2, N3, N4). The results showed that the grain yield and $\mathrm{N}$ uptake did not differ significantly among treatments. $\mathrm{N}$ from fertilizer taken up (Ndff) by wheat was not affected by $\mathrm{N}$ management; however, in maize, Ndff performed differently. Optimized treatments significantly decreased the Ndff as compared to N1 treatment. Furthermore, NRE of wheat and annual nitrogen recovery efficiency (annual NRE) did not differ among treatments in 2016 but significantly increased in 2017 compared to N1. Annual NRE in 2017 was similar to that obtained for wheat. For maize, optimized N managements decreased the NRE in N3 and N4 treatments of two years. Potential losses in wheat were also similar amongst treatments, but in maize, N3 and N4 had lower residual N in the soil's top $60 \mathrm{~cm}$ but resulted in higher potential losses than N1 and N2. Overall, our results demonstrate that applying $420 \mathrm{~kg} \mathrm{~N}^{-1}$ annually in three applications and combining SRF and urea are effective to sustain crop yield, improve the efficiency of $\mathrm{N}$ usage by maize, and reduce $\mathrm{N}$ losses in this region.
\end{abstract}

Keywords: excessive $\mathrm{N}$ application; $\mathrm{N}$ distribution; ${ }^{15} \mathrm{~N}$-labelled urea; optimized $\mathrm{N}$ management; $\mathrm{N}$ use efficiency; $\mathrm{N}$ losses

\section{Introduction}

The efficient use of nitrogen $(\mathrm{N})$ is becoming gradually important in agricultural fields because it can reduce the input of fertilizer and improve $\mathrm{N}$ use efficiency (NUE). However, over the last few decades, applying a large amount of chemical fertilizer to increase the crop yield has become more and more common. In recent years, the use of the chemical $\mathrm{N}$ in China has accounted for $32 \%$ of the world's total use [1]. In some regions of China, the $\mathrm{N}$ application rate was as high as $325 \mathrm{~kg} \mathrm{~N} \mathrm{ha}^{-1}$ for wheat and $257 \mathrm{~kg} \mathrm{~N} \mathrm{ha}^{-1}$ for maize. In Shandong province, the $\mathrm{N}$ application rate was $553 \mathrm{~kg} \mathrm{~N} \mathrm{ha}^{-1}$ in the wheat-maize rotation system [2,3]. In investigating other regions of North China, traditionally, the $\mathrm{N}$ rate for farmers was more than $500 \mathrm{~kg} \mathrm{ha}^{-1}$ year $^{-1}$ for the intensive 
wheat-maize system and approached $600 \mathrm{~kg} \mathrm{ha}^{-1}$ year ${ }^{-1}$ in recent years to pursue high crop yields $[3,4]$. It is higher than other developed countries as well as the world average [5]. Additionally, smallholders invariably apply a large proportion of $\mathrm{N}$ as basal fertilizer and generally apply topdressing at the wintering stage for wheat and at the bell stage for maize. The fertilizers are applied four times annually [6]. Clearly, this $\mathrm{N}$ practice contributed to a large amount of $\mathrm{N}$ fertilizer input in the early growth stages, which results in poor synchrony between soil $\mathrm{N}$ supply and crop demand $[7,8]$. Several factors are assumed to contribute to higher fertilizer consumption in the wheat-maize rotation system. One is that the cropland is managed by hundreds of millions of farmers which leads to the rates of fertilizer application by different farmers varying widely. Regardless of soil fertility and crop potential production, farmers still believe that more fertilizer input, the higher grain yield is achieved $[2,9]$. A further important factor is that being restricted by old knowledge and habits, farmers lack basic information on crop yield response to $\mathrm{N}$ fertilizer. Small-scale farming has resulted in high fertilizer input to achieve higher crop production in limited areas of land. Worldwide, high $\mathrm{N}$ has contributed to higher crop yield, but it has also led to lower economic returns for farmers and loss of more than $50 \%$ of the applied $\mathrm{N}$ to the environment $[10,11]$. Lower nitrogen recovery efficiency (NRE), and different environmental consequences, such as soil acidification, $\mathrm{N}$ leaching, ammonia volatilization, and groundwater contamination etc. are becoming ever more serious [11-13]. This phenomenon is particularly of concern in intensive cropping systems [2,14,15]. Therefore, it is essential to resolve the contradictions between optimizing $\mathrm{N}$ fertilization management to improve NRE, crop yield, economic returns, and the environment. In the wheat-maize rotation system, some studies have shown that cutting in half the additions of $\mathrm{N}$ fertilizer will not reduce the yield, and could decrease $\mathrm{N}$ losses by $50 \%$ [16,17]. Clearly, a rational $\mathrm{N}$ fertilizer management has been considered a key challenge for sustaining crop yield and restoring balance to the environment.

At present, the sustainable development of agriculture has been gaining more and more public attention. Great progress has been made in optimizing management for NUE [18]. To optimize $\mathrm{N}$ management, nitrification inhibitors, fertilizer deep placement, and controlled-release urea are utilized [15,19,20]. Ju et al. [17] and Zhao et al. [21] have already reported that adopting optimum $\mathrm{N}$ fertilization techniques and controlling the primary $\mathrm{N}$ loss pathways can decrease the negative effect of excessive $\mathrm{N}$ fertilizer on crop quality, NUE, and environmental risk in rice/wheat cultivation. In recent years, slow-release fertilizer (SRF) was introduced to agriculture, which was designed to release $\mathrm{N}$ into the soil at a rate that can closely match crop nutrient absorption [22]. Some studies have found that SRF not only improves NUE but also decreases $\mathrm{N} / \mathrm{NO}_{3}{ }^{-}$leaching. Moreover, SRF has been considered a time- and labor-saving phenomenon, as it only needs a one-time application, as opposed to conventional urea $[20,23]$. Other studies have focused on improving NRE by decreasing $N$ losses by adjusting the $\mathrm{N}$ rate and the ratio of basal to topdressing fertilization. The experimental data of Lopez-Bellido et al. [24] and Cui et al. [25] showed that increasing topdressing $\mathrm{N}$ fertilizer at a suitable ratio can increase grain yield, plant $\mathrm{N}$ uptake, and NRE. However, the majority of studies focused on a single crop or optimized $\mathrm{N}$ practice on a single crop, only a few studies focused on the wheat-maize rotation system that is dominant in northern China. Therefore, this study explores the effects of different annual $\mathrm{N}$ fertilization strategies (including rate, timing, and SRF) to optimize conventional fertilizer management on a wheat-maize rotation system. To this end, the ${ }^{15} \mathrm{~N}$ tracer technique was used to trace the fate of fertilizer or residual $\mathrm{N}$ in the soil. Its use allows a clear analysis of crop $\mathrm{N}$ uptake, $\mathrm{NRE}$, and $\mathrm{N}$ losses from leaching or volatilization [26-29]. In this study, we evaluate the different annual $\mathrm{N}$ managements in terms of NRE, $\mathrm{N}$ distribution in plant and soil, and $\mathrm{N}$ losses. By adjusting the $\mathrm{N}$ application ratio from basal to topdressing and combining this with SRF, an effective fertilizer management strategy can be developed for sustained crop yield, improving NRE, and mitigating potential $\mathrm{N}$ losses from the agro-ecosystem. 


\section{Materials and Methods}

\subsection{Description of Experimental Plot}

A two-year experiment included two subsequent winter wheat-summer maize rotations that were conducted at Doukou Experiment Station, Northwest A\&F University, Shaanxi Province, China $\left(34^{\circ} 36^{\prime} \mathrm{N}, 108^{\circ} 52^{\prime} \mathrm{E}\right.$; altitude $\left.427.4 \mathrm{~m}\right)$ from 15 October 2015 to 9 October 2017. This area has the typical dry semi-humid climate of northwest China. The rainfall during the wheat and maize growing seasons was 217.2 and $230.1 \mathrm{~mm}$ in 2016 and 2017, respectively. About $60-70 \%$ of the annual rainfall is concentrated in summer, falling from May to August, and monthly rainfall is unevenly distributed. Furthermore, the rainfall in the two years varied and cannot meet the growth of crops. So moderate irrigation was necessary to make all treatments free of potential drought stress throughout the whole crop growing seasons (according to the dynamic variation of soil moisture). The highest monthly temperature $\left(28.8^{\circ} \mathrm{C}\right.$ ) occurred in August in 2016 and in July $\left(29.9^{\circ} \mathrm{C}\right)$ in 2017 (Figure 1). Weather data were collected with an automatic weather station (Vantage Pro2, Davis Instruments Corporation, San Francisco, CA, USA). The winter wheat-summer maize rotation system is the major cultivation practice in this area [6]. The soil at the research site was loamy clay; the soil properties of the top $20 \mathrm{~cm}$ are shown in Table 1, and the information of the chemical properties of the topsoil was described previously by Liang et al. [6].

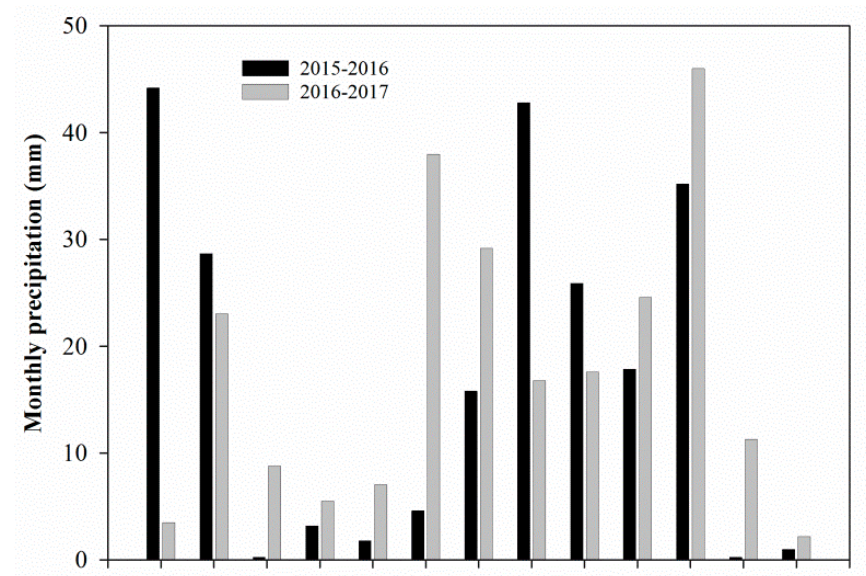

Oct Nov Dec Jan Feb Mar Apr May Jun Jul Aug Sep Oct

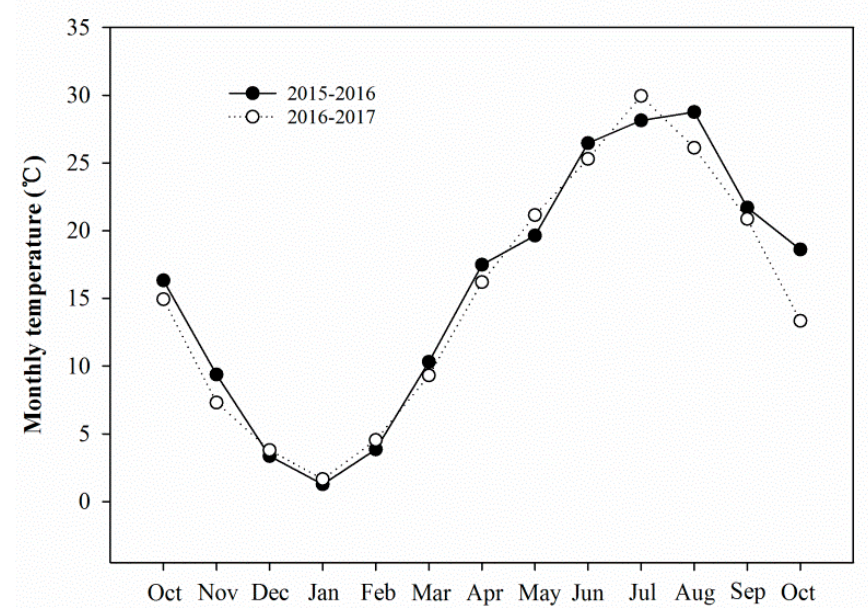

Figure 1. Monthly temperature and annual rainfall during the wheat-maize growing seasons in 2015-2016 and 2016-2017 in the North China Plain (NCP). 
Table 1. Properties of the top-soil layer $(0-20 \mathrm{~cm})$ in the experimental field at Doukou, Shaanxi in 2015.

\begin{tabular}{cccccc}
\hline Year & pH & SOM (g/kg) & TN (g/kg) & AK (mg/kg) & AP (mg/kg) \\
\hline 2015 & 8.6 & 18.88 & 1.54 & 397.07 & 18.56 \\
\hline
\end{tabular}

SOM: soil organic matter; TN: total nitrogen; AK: available potassium; AP: available phosphorus. The data was published previously in Liang et al. [6].

\subsection{Experimental Set-Up}

The experiment included four different annual $\mathrm{N}$ application treatments: the conventional $\mathrm{N}$ fertilization treatment with an annual application rate of $510 \mathrm{~kg} \mathrm{~N} \mathrm{ha}^{-1}$ and three optimized $\mathrm{N}$ treatments with reducing annual $\mathrm{N}$ application rate to $420 \mathrm{~kg} \mathrm{~N} \mathrm{ha}^{-1}$; the basal $\mathrm{N}$ was applied the day before sowing and topdressing N at GS24 [(70 days after sowing (DAS)], GS39 (175 DAS) of wheat, and V6, V12 of maize. Detailed N fertilizer application schemes are shown in Table 2 and the treatments were described previously by Liang et al. [6]. Additionally, the control without $\mathrm{N}$ was included. The plots were arranged in a randomized block design with three replications and the area of each plot was $49 \mathrm{~m}^{2}(7 \times 7 \mathrm{~m})$. The $\mathrm{N}$ application practice of $\mathrm{N} 1$ for both crops was surveyed and followed the custom of local farmers. $\mathrm{N}$ fertilizer was applied in the form of urea $(46 \% \mathrm{~N})$ and SRF $(28 \% \mathrm{~N})$. The SRF was supplied by the Stanley Agricultural Group Co., Ltd., (Linyi, China) and the N release period of the SRF was three months in water and longer in soil [30]. To each plot, phosphate (P) and potassium (K) fertilizers were applied basally at $120\left(\mathrm{P}_{2} \mathrm{O}_{5}\right) \mathrm{kg} \mathrm{ha}^{-1}$ and $30\left(\mathrm{~K}_{2} \mathrm{O}\right) \mathrm{kg} \mathrm{ha}^{-1}$, respectively, before sowing and incorporated to a depth of 10-15 cm by rotary tillage. Topdressing fertilizer was placed in the soil at a depth of $10 \mathrm{~cm}$ following irrigation. Wheat cultivar Xiaoyan 22 and maize cultivar Zhengdan 958 were used, which are widely used cultivars on the North China plain. The wheat crop was sown on 15 October 2015 and 11 October 2016 at a rate of $150 \mathrm{~kg} \mathrm{ha}^{-1}$ and a spacing of $25 \mathrm{~cm}$; the maize was sown immediately after the wheat harvest with a density of 100,000 plants ha $^{-1}$. The row and plant spacing of maize were 40 and $20 \mathrm{~cm}$, respectively. Other farm management followed local practice.

To monitor the fate of ${ }^{15} \mathrm{~N}$-labeled fertilizer, each plot contained a ${ }^{15} \mathrm{~N}$ isotope microplot using a PVC pipe with a height of $60 \mathrm{~cm}$ and a diameter of $30 \mathrm{~cm}$ in the southwestern side of the experimental plot in the wheat season. In all the microplots, the same plant spacing was used as the corresponding main plots. All the pipes were kept $5 \mathrm{~cm}$ above the soil to prevent runoff and lateral contamination with unlabeled fertilizer. In the maize season, the microplots were moved to the northwestern side of the plots. ${ }^{15} \mathrm{~N}$-labeled urea, with an abundance of $10.21 \%$, was adopted in both the wheat and maize season (provided by the Shanghai Research Institute of Chemical Industry) and applied at the same dosage as in the corresponding main plot. 
Table 2. Annual nitrogen $(\mathrm{N})$ treatments in the wheat-maize double cropping system.

\begin{tabular}{|c|c|c|c|c|c|c|c|c|c|}
\hline \multirow[b]{2}{*}{ Treatment } & \multirow[b]{2}{*}{ Annual N } & \multicolumn{4}{|c|}{ Wheat } & \multicolumn{4}{|c|}{ Maize } \\
\hline & & Appl. No & $\begin{array}{l}\text { N Rate } \\
\text { kg ha }^{-1}\end{array}$ & Fertilizer Type & Growth Stage & Appl. No & $\begin{array}{l}\text { N Rate } \\
\text { kg ha }^{-1}\end{array}$ & Fertilizer Type & Growth Stage \\
\hline${ }^{\mathrm{a}} \mathrm{N} 1$ & 510 & 2 & 270 & b U210-U60 & B + GS24 & 2 & 240 & U120+U120 & $\mathrm{B}+\mathrm{V} 12$ \\
\hline N2 & 420 & 2 & 210 & U120-U90 & B + GS39 & 2 & 210 & U90+U120 & $\mathrm{V} 6+\mathrm{V} 12$ \\
\hline N3 & 420 & 2 & 210 & U120-U90 & B + GS39 & 1 & 210 & SRF210 & V6 \\
\hline N4 & 420 & 2 & 210 & U120-U90 & B + GS39 & 1 & 210 & (U:SRF)210 & V6 \\
\hline
\end{tabular}

a The treatments (N1, N2, N3, N4) were described by Liang et al. [6]. ${ }^{b} \mathrm{U}$ represents normal urea; SRF represents slow-release fertilizer, U:SRF represents a mixed fertilizer with an SRF: urea ratio of 1:1. B denotes basal N; GS24 and GS39 denote topdressing N at the wintering stage and the jointing stage, respectively. V6 and V12 denote topdressing N at the six-leaf stage and the twelve-leaf stage, respectively. 


\subsection{Plant and Soil Sampling Analysis}

Whole wheat and maize plant samples in each microplot were harvested at maturity; they were divided into two parts to determine the total $\mathrm{N}$ content and for isotopic analysis. The plants of wheat were divided into straw and grain for analysis in both years. For maize, the samples were divided into stems (including cobs), leaves and grain in 2016 but in 2017, the isotopic analysis was done using the whole plant. The grain protein was also measured using a near-infrared Grain Analyzer (DA7250, Perten Company, Hägersten, Sweden). After harvest, soil samples in each microplot were collected to a depth of $60 \mathrm{~cm}(0-20 \mathrm{~cm}, 20-40 \mathrm{~cm}$, and $40-60 \mathrm{~cm})$ using a soil auger at $20 \mathrm{~cm}$ intervals. Plant total $\mathrm{N}$ was analyzed using the Kjeldahl method. The ${ }^{15} \mathrm{~N}$ enrichment in plant and soil were measured by elemental analysis isotope ratio mass spectrometry (EA-IRMS), using an Organic Elemental Analyser (FLASH 2000) in conjunction with an isotope mass spectrometer (MAT-253, Thermo Fisher, Bremen, Germany). The sample materials were weighed $(<1 \mathrm{mg})$ and wrapped in a tin cup, then loaded into a Flash EA 2000 automatic sampler before EA-IRMS analysis [31]. The ${ }^{15} \mathrm{~N}$ is expressed as the atom excess corrected for background abundance $(0.366 \%)$.

The percentage of nitrogen derived from fertilizer (Ndff) and the soil residual $\mathrm{N}(\mathrm{Ndfs})(\%)$, $\mathrm{N}$ recovery efficiency $(\%), \mathrm{N}$ residual efficiency $(\%)$, and potential $\mathrm{N}$ losses $(\%)$ were calculated according to Equations (1)-(6), respectively, referring to the methods of Halitligil et al., Yang et al. [32,33], and Wang et al. [34].

$$
\begin{gathered}
\text { Ndff }(\%)=\frac{\text { at } \%{ }^{15} \mathrm{~N} \text { atom excess }(\text { plant })-{ }^{15} \mathrm{~N} \text { natural abundance }}{\text { at } \%{ }^{15} \mathrm{~N} \text { atom excess }(\text { fertilizer })-{ }^{15} \mathrm{~N} \text { natural abundance }} \times 100 \\
\mathrm{Ndfs}(\%)=100-(1) \\
\mathrm{Ndff}(\mathrm{kg} / \mathrm{ha})=\mathrm{N} \text { uptake in plant } \times(1) \\
\mathrm{N} \text { recovery efficiency }(\%)=\frac{\text { Plant }{ }^{15} \mathrm{~N} \text { from fertilizer }(\mathrm{kg} / \mathrm{ha})}{{ }^{15} \mathrm{~N} \text { application rate }(\mathrm{kg} / \mathrm{ha})} \times 100 \\
\mathrm{~N} \text { residual efficiency }(\%)=\frac{\text { Residual }{ }^{15} \mathrm{~N} \text { in soil }(\mathrm{kg} / \mathrm{ha})}{{ }^{15} \mathrm{~N} \text { application rate }(\mathrm{kg} / \mathrm{ha})} \times 100 \\
\text { Potential } \mathrm{N} \text { losses }(\%)=100-(4)-(5)
\end{gathered}
$$

All data were analyzed by one-way analysis of variance (ANOVA). Statistical analyses were done using SPSS version 20.0 software (SPSS Inc., Chicago, IL, United States), and the least significant difference (LSD) at the $5 \%$ level was used to compare the treatments. Graphs were prepared by using Sigmaplot 12.5 .

\section{Results}

\subsection{Effect of Nitrogen Management on Yield and Protein of Wheat and Maize}

All fertilized $\mathrm{N}$ treatments were significantly different than the N0 treatment, showing an increase in grain yield, plant $\mathrm{N}$ uptake in wheat and maize seasons. The yields of winter wheat and summer maize were not affected by the optimal N application practice in 2016 and 2017 (Table 3). The N uptake of wheat and maize showed the same pattern as the yield in both growing seasons and there were also no significant differences among treatments. After harvesting, the crude protein (butt) of grains was analyzed, and the results revealed that annual $\mathrm{N}$ managements did not affect the crude protein of wheat and maize in either year (Table 4). In N0 treatment, the crude protein was significantly lower than the fertilized $\mathrm{N}$ treatments. 
Table 3. Crop yield and $\mathrm{N}$ uptake under different nitrogen treatments in a wheat-maize double cropping system.

\begin{tabular}{|c|c|c|c|c|c|c|c|c|c|c|}
\hline \multirow[t]{2}{*}{ Treatment } & \multicolumn{2}{|c|}{$\begin{array}{l}\text { Wheat Yield } \\
\quad\left(t \mathrm{ha}^{-1}\right)\end{array}$} & \multicolumn{2}{|c|}{$\begin{array}{l}\text { Maize Yield } \\
\quad\left(\mathrm{t} \mathrm{ha}^{-1}\right)\end{array}$} & \multicolumn{2}{|c|}{$\begin{array}{l}\text { Annual Yield } \\
\qquad\left(t h^{-1}\right)\end{array}$} & \multicolumn{2}{|c|}{$\begin{array}{c}\text { Wheat } \\
\text { N Uptake } \\
\left(\mathrm{kg} \mathrm{ha}^{-1}\right)\end{array}$} & \multicolumn{2}{|c|}{$\begin{array}{c}\text { Maize } \\
\text { N Uptake } \\
\left(\mathrm{kg} \mathrm{ha}^{-1}\right)\end{array}$} \\
\hline & 2016 & 2017 & 2016 & 2017 & 2016 & 2017 & 2016 & 2017 & 2016 & 2017 \\
\hline No & $5.4 \mathrm{~b}$ & $5.9 \mathrm{~b}$ & $4.4 \mathrm{~b}$ & $5.8 \mathrm{~b}$ & $9.8 \mathrm{~b}$ & $11.7 \mathrm{~b}$ & $147.2 \mathrm{~b}$ & $172.7 \mathrm{~b}$ & $129.3 b$ & $186.2 b$ \\
\hline N1 & $7.5 a$ & $8.7 a$ & $9.6 a$ & $8.9 a$ & $16.8 \mathrm{a}$ & $17.7 \mathrm{a}$ & $223.3 a$ & $334.2 \mathrm{a}$ & $263.8 \mathrm{a}$ & $371.8 \mathrm{a}$ \\
\hline N2 & $7.2 \mathrm{a}$ & $9.3 a$ & $9.5 a$ & $8.4 a$ & $17.1 \mathrm{a}$ & $17.8 \mathrm{a}$ & $256.1 \mathrm{a}$ & $331.9 a$ & $277.3 a$ & $353.2 \mathrm{a}$ \\
\hline N3 & $7.3 a$ & $9.4 \mathrm{a}$ & $9.9 \mathrm{a}$ & $9.1 \mathrm{a}$ & $17.1 \mathrm{a}$ & $18.5 \mathrm{a}$ & $254.2 \mathrm{a}$ & $334.5 \mathrm{a}$ & $237.2 \mathrm{a}$ & $396.8 \mathrm{a}$ \\
\hline N4 & $7.1 \mathrm{a}$ & $9.7 a$ & $9.5 a$ & $9.0 \mathrm{a}$ & $16.7 \mathrm{a}$ & $18.7 \mathrm{a}$ & $243.3 a$ & $366.6 a$ & $285.6 a$ & $373.0 \mathrm{a}$ \\
\hline
\end{tabular}

Different letters within a column represent significant differences $(p<0.05)$. The data for crop yield was published previously in Liang et al. [6].

Table 4. Crude protein of grains under different nitrogen treatments after harvest.

\begin{tabular}{ccccc}
\hline \multirow{2}{*}{ Treatment } & \multicolumn{2}{c}{ Wheat } & \multicolumn{2}{c}{ Maize } \\
\cline { 2 - 5 } & $\mathbf{2 0 1 6}$ & $\mathbf{2 0 1 7}$ & $\mathbf{2 0 1 6}$ & $\mathbf{2 0 1 7}$ \\
\hline & $\begin{array}{c}\text { Crude } \\
\text { protein }(\%)\end{array}$ & $\begin{array}{c}\text { Crude } \\
\text { protein }(\%)\end{array}$ & $\begin{array}{c}\text { Crude } \\
\text { protein }(\%)\end{array}$ & $\begin{array}{c}\text { Crude } \\
\text { protein }(\%)\end{array}$ \\
\cline { 2 - 5 } & $13.8 \mathrm{~b}$ & $12.1 \mathrm{~b}$ & $7.3 \mathrm{~b}$ & $9.7 \mathrm{~b}$ \\
N0 & $14.7 \mathrm{a}$ & $14.3 \mathrm{a}$ & $8.1 \mathrm{a}$ & $11.6 \mathrm{a}$ \\
N1 & $14.7 \mathrm{a}$ & $13.9 \mathrm{ab}$ & $8.0 \mathrm{a}$ & $10.8 \mathrm{a}$ \\
N2 & $14.6 \mathrm{a}$ & $13.9 \mathrm{ab}$ & $7.9 \mathrm{ab}$ & $10.7 \mathrm{ab}$ \\
N3 & $14.3 \mathrm{a}$ & $14.5 \mathrm{a}$ & $8.4 \mathrm{a}$ & $10.8 \mathrm{a}$ \\
$\mathrm{N} 4$ & &
\end{tabular}

Different letters within a column represent significant differences $(p<0.05)$.

\subsection{Plant N Derived from Fertilizer and Soil}

In 2016 and 2017 winter wheat seasons, the $\mathrm{N}$ uptake in the straw of wheat derived from ${ }^{15} \mathrm{~N}$-labeled urea (Ndff), and from the soil (Ndfs) did not differ significantly in the treatments, where the $\mathrm{N}$ rate was reduced or where topdressing was moved to the jointing stage compared with that of treatment $\mathrm{N} 1$. The grain's $\mathrm{N}$ uptake from ${ }^{15} \mathrm{~N}$-labeled fertilizer showed a similar trend to the straw that is showed in Table 5. The distribution of ${ }^{15} \mathrm{~N}$ among these organs was as follows: grain > straw. The total $\mathrm{N}$ uptake in both years from the fertilizer (Ndff) and soil (Ndfs) was also not different among all treatments. However, the $\mathrm{N}$ derived from fertilizer (Ndff) in the maize plant performed differently (Table 5). There was a significant difference between treatments N1 and N3 and N4; Ndff in the different organs (straw and grain) was higher in N1 than in treatments N3 and N4 in 2016. Additionally, the ${ }^{15} \mathrm{~N}$ among the different organs in maize was as follows: grain > straw. Among the optimized $\mathrm{N} 3$ and N4 treatments, there were no significant differences. The ${ }^{15} \mathrm{~N}$ in the straw derived from soil (Ndfs) did not differ among treatments. However, in optimal $\mathrm{N}$ treatments, the Ndfs of grain were higher than the $\mathrm{N} 1$ treatment. Regarding total ${ }^{15} \mathrm{~N}$ uptake, the ${ }^{15} \mathrm{~N}$ derived from fertilizer (Ndff) in N1 and N2 was significantly different from that in N3 and N4. The total Ndff was lower in treatments $\mathrm{N} 3$ and N4, but the total Ndfs was not different among treatments. In 2017, the ${ }^{15} \mathrm{~N}$ uptake by the whole plant was measured and the result indicated a similar pattern to the ${ }^{15} \mathrm{~N}$ uptake of maize in 2016 (Table 5). Regarding the annual ${ }^{15} \mathrm{~N}$ uptake, there was no significant difference between all the treatments in either year (Table 6). The total $\mathrm{N}$ uptake by wheat consisted of $40.5-42.5 \%$ of fertilizer ${ }^{15} \mathrm{~N}$ and $57.5-59.5 \%$ of soil $\mathrm{N}$ in 2016 and $36.4-39.0 \%$ and $61.0-63.6 \%$ in 2017 , respectively. The total $\mathrm{N}$ uptake by maize consisted of $11.9-30.3 \%$ of fertilizer ${ }^{15} \mathrm{~N}$ and $69.7 .7-88.1 \%$ of soil $\mathrm{N}$ in 2016 and $13.3-21.8 \%$ and $78.2-86.7 \%$ in 2017 , respectively. The $\mathrm{N}$ derived from soil (Ndfs) in wheat and maize plants was more than what was derived from fertilizer (Ndff). This indicates that soil $\mathrm{N}$ is particularly important for the plant. 
After the wheat harvest, the residual $\mathrm{N}(\%)$ of the soil from fertilizer in the top 0-60 cm was analyzed and the result demonstrated that the $\mathrm{N}$ residual from treatment $\mathrm{N} 1$ was higher than that from other treatments, followed by N2, while treatments N3 and N4 were not significantly different in 2016 and 2017 (Table 7). In both years, after the maize harvest, the $\mathrm{N}$ residual of the soil displayed a similar trend to that after the wheat harvest. The annual residual was also taken into consideration and the results presented were similar in the two annual crop growing seasons. There was more residual $\mathrm{N}$ in the soil in treatment $\mathrm{N} 1$, followed by $\mathrm{N} 2$, while the soil residual in treatments $\mathrm{N} 3$ and N4 was lower. Moreover, the residual of the application mostly remained in the topsoil layer. The $\mathrm{N}$ recovery efficiency rate in wheat was not affected by the $\mathrm{N}$ application practice in 2016 but significantly higher in 2017 in optimal N treatments compared with N1. Furthermore, it greatly affected the maize when the N application rate decreased. In terms of annual $\mathrm{N}$ recovery efficiency, integrated $\mathrm{N}$ management showed a similar trend to wheat in two years of rotation. Table 7 also provided the loss of the ${ }^{15} \mathrm{~N}$-labeled urea and the results showed that the potential loss did not differ among treatments in the wheat-growing seasons in 2016 and 2017. However, in the maize-growing seasons of both years, the loss rates were opposite to that in the wheat-growing seasons and in treatments N3 and N4, the losses were higher than in N1 and N2. This means the potential loss of $\mathrm{N}$ was higher when $\mathrm{N}$ was applied once, even though the $\mathrm{N}$ application rate was reduced. 
Table 5. $\mathrm{N}$ uptake from ${ }^{15} \mathrm{~N}$-labeled urea by wheat and maize after harvest in 2016 and 2017 under different $\mathrm{N}$ fertilizer treatments.

\begin{tabular}{|c|c|c|c|c|c|c|c|c|c|c|c|c|c|}
\hline \multirow[t]{3}{*}{ Crop } & \multirow[t]{3}{*}{ Treatment } & \multicolumn{2}{|c|}{ Ndff $\left(\mathrm{kg} \mathrm{ha}^{-1}\right)$} & \multicolumn{2}{|c|}{ Ndfs (kg ha $\left.{ }^{-1}\right)$} & \multicolumn{2}{|c|}{ Ndff (kg ha $\left.{ }^{-1}\right)$} & \multicolumn{2}{|c|}{ Ndfs (kg ha $\left.{ }^{-1}\right)$} & $\begin{array}{c}\text { Ndff } \\
\left(\mathrm{kg} \mathrm{ha}^{-1}\right)\end{array}$ & $\begin{array}{c}\text { Ndfs } \\
\left(\mathrm{kg} \mathrm{ha}^{-1}\right)\end{array}$ & $\begin{array}{c}\text { Ndff } \\
\left(\mathrm{kg} \mathrm{ha}^{-1}\right)\end{array}$ & $\begin{array}{c}\text { Ndfs } \\
\left(\mathrm{kg} \mathrm{ha}^{-1}\right)\end{array}$ \\
\hline & & \multicolumn{4}{|c|}{ Straw $(\mathrm{S})$} & \multicolumn{4}{|c|}{ Grain $(\mathrm{G})$} & \multirow{2}{*}{\multicolumn{2}{|c|}{ Total of 2016}} & \multirow{2}{*}{\multicolumn{2}{|c|}{ Total of 2017}} \\
\hline & & 2016 & 2017 & 2016 & 2017 & 2016 & 2017 & 2016 & 2017 & & & & \\
\hline \multirow{5}{*}{ Winter wheat } & N0 & - & - & - & - & - & - & - & - & - & $147.2 \mathrm{~b}$ & - & $172.7 \mathrm{~b}$ \\
\hline & N1 & $23.5 \mathrm{a}$ & $38.4 \mathrm{a}$ & $40.8 \mathrm{a}$ & $68.2 a$ & $71.3 a$ & $83.3 a$ & $87.7 \mathrm{a}$ & $144.3 a$ & $94.8 \mathrm{a}$ & $128.5 a$ & $121.7 \mathrm{a}$ & $212.5 \mathrm{a}$ \\
\hline & $\mathrm{N} 2$ & $30.0 \mathrm{a}$ & $36.8 \mathrm{a}$ & $51.4 \mathrm{a}$ & $61.0 \mathrm{a}$ & $73.6 a$ & $88.6 \mathrm{a}$ & $101.2 \mathrm{a}$ & $145.5 a$ & $103.6 a$ & $152.5 a$ & $125.3 a$ & $206.6 a$ \\
\hline & N3 & $26.4 a$ & $39.4 a$ & $46.3 a$ & $65.6 a$ & $79.2 \mathrm{a}$ & $91.0 \mathrm{a}$ & $102.3 a$ & $138.5 a$ & $105.6 a$ & $148.6 a$ & $130.4 a$ & $204.1 \mathrm{a}$ \\
\hline & $\mathrm{N} 4$ & $23.4 \mathrm{a}$ & $40.0 \mathrm{a}$ & $41.6 a$ & $68.3 a$ & $77.0 \mathrm{a}$ & $98 \mathrm{a}$ & 101.3a & $160.4 a$ & $100.3 a$ & $143.0 \mathrm{a}$ & $138.0 \mathrm{a}$ & $228.6 a$ \\
\hline & & \multicolumn{4}{|c|}{$\operatorname{Straw}(\mathrm{S}+\mathrm{C}+\mathrm{L})$} & \multicolumn{4}{|c|}{ Grain $(G)$} & \multicolumn{2}{|c|}{ Total of 2016} & \multicolumn{2}{|c|}{ Total of 2017} \\
\hline \multirow{5}{*}{ Summer maize } & No & - & - & - & - & - & - & - & - & - & $129.3 \mathrm{~b}$ & - & $186.2 \mathrm{~b}$ \\
\hline & N1 & $33.3 a$ & - & $62.9 \mathrm{ab}$ & - & $46.5 a$ & - & $121.0 \mathrm{~b}$ & - & $79.8 \mathrm{a}$ & $184.0 \mathrm{a}$ & $81.1 \mathrm{a}$ & $290.7 a$ \\
\hline & N2 & $18.1 \mathrm{~b}$ & - & $62.1 \mathrm{ab}$ & - & $46.0 \mathrm{a}$ & - & $151.0 \mathrm{ab}$ & - & $64.1 \mathrm{a}$ & $213.2 a$ & $64.5 \mathrm{~b}$ & $288.7 \mathrm{a}$ \\
\hline & N3 & $13 b$ & - & $62.8 \mathrm{ab}$ & - & $16.5 b$ & - & $144.9 \mathrm{ab}$ & - & $29.5 b$ & $207.7 a$ & $52.8 \mathrm{~b}$ & $343.9 a$ \\
\hline & $\mathrm{N} 4$ & $14.9 \mathrm{~b}$ & - & $65.5 a$ & - & $19.0 \mathrm{~b}$ & - & $186.3 a$ & - & $33.9 \mathrm{~b}$ & $251.8 \mathrm{a}$ & $58.9 \mathrm{~b}$ & $314.1 \mathrm{a}$ \\
\hline
\end{tabular}

Different letters within a column represent significant differences $(p<0.05)$. Ndff represents $\mathrm{N}$ from ${ }^{15} \mathrm{~N}$-labelled urea; Ndfs represents $\mathrm{N}$ from soil (total $\mathrm{N}$ uptake- $\mathrm{Ndff}$; wheat straw includes stem and leaf; maize straw includes stem, leaf and cob.

Table 6. Annual $\mathrm{N}$ uptake from ${ }^{15} \mathrm{~N}$-labeled urea by winter wheat and summer maize in 2016 and 2017.

\begin{tabular}{|c|c|c|c|c|c|c|c|c|c|c|}
\hline Treatment & Crop & $\begin{array}{c}\text { Ndff/N } \\
\text { Uptake (\%) }\end{array}$ & $\begin{array}{c}\text { Ndfs/N } \\
\text { Uptake (\%) }\end{array}$ & $\begin{array}{c}\text { Ndff/N } \\
\text { Uptake (\%) }\end{array}$ & $\begin{array}{c}\text { Ndfs/N } \\
\text { Uptake (\%) }\end{array}$ & & $\begin{array}{c}\text { Ndff } \\
\left(\mathrm{kg} \mathrm{ha}^{-1}\right)\end{array}$ & $\begin{array}{c}\text { Ndfs } \\
\left(\mathrm{kg} \mathrm{ha}^{-1}\right)\end{array}$ & $\begin{array}{c}\text { Ndff } \\
\left(\mathrm{kg} \mathrm{ha}^{-1}\right)\end{array}$ & $\begin{array}{c}\text { Ndfs } \\
\left(\mathrm{kg} \mathrm{ha}^{-1}\right)\end{array}$ \\
\hline & & 2016 & 2016 & 2017 & 2017 & & \multicolumn{2}{|c|}{ Annual of 2016} & \multicolumn{2}{|c|}{ Annual of 2017} \\
\hline N1 & \multirow{4}{*}{ Winter wheat } & 42.5 & 57.5 & 36.4 & 63.6 & \multirow{4}{*}{ Rotation system } & $174.6 \mathrm{a}$ & $312.5 a$ & $202.8 \mathrm{a}$ & $503.2 \mathrm{a}$ \\
\hline N2 & & 40.5 & 59.5 & 37.8 & 62.2 & & $167.7 \mathrm{a}$ & $365.7 \mathrm{a}$ & $189.8 \mathrm{a}$ & $495.3 \mathrm{a}$ \\
\hline N3 & & 41.5 & 58.5 & 39.0 & 61.0 & & $135.1 \mathrm{a}$ & $356.3 a$ & $198.8 \mathrm{a}$ & $548.0 \mathrm{a}$ \\
\hline N4 & & 41.2 & 58.8 & 37.6 & 62.4 & & $134.2 \mathrm{a}$ & $394.7 \mathrm{a}$ & $196.9 a$ & $542.7 \mathrm{a}$ \\
\hline N1 & \multirow{4}{*}{ Summer maize } & 30.3 & 69.7 & 21.8 & 78.2 & & & & & \\
\hline N2 & & 23.1 & 76.9 & 18.3 & 81.7 & & & & & \\
\hline N3 & & 12.4 & 87.6 & 13.3 & 86.7 & & & & & \\
\hline N4 & & 11.9 & 88.1 & 15.8 & 84.2 & & & & & \\
\hline
\end{tabular}

Different letters within a column represent significant differences $(p<0.05)$. Ndff represents $\mathrm{N}$ from ${ }^{15} \mathrm{~N}$-labelled urea; Ndfs represents $\mathrm{N}$ from soil (total $\mathrm{N}$ uptake- $\mathrm{Ndff}$ ). 
Table 7. The fate of ${ }^{15} \mathrm{~N}$-labeled urea in wheat-maize rotation system in 2016 and 2017.

\begin{tabular}{|c|c|c|c|c|c|c|c|c|c|c|c|c|c|c|c|c|}
\hline \multirow[t]{3}{*}{ Treatment } & \multicolumn{2}{|c|}{ Wheat } & \multicolumn{2}{|c|}{ Maize } & \multicolumn{2}{|c|}{ Wheat } & \multicolumn{2}{|c|}{ Maize } & \multicolumn{2}{|c|}{ Wheat } & \multicolumn{2}{|c|}{ Maize } & \multicolumn{4}{|c|}{ Annual } \\
\hline & \multicolumn{4}{|c|}{ Plant Recovery (\%) } & \multicolumn{4}{|c|}{$\begin{array}{l}\text { Soil Residual (\%) } \\
\qquad(0-60 \mathrm{~cm})\end{array}$} & \multicolumn{4}{|c|}{ Potential Losses (\%) } & \multicolumn{2}{|c|}{$\begin{array}{c}\begin{array}{c}\text { Plant Recovery } \\
(\%)\end{array} \\
\end{array}$} & \multicolumn{2}{|c|}{$\begin{array}{c}\text { Soil Residual } \\
\text { (\%) }\end{array}$} \\
\hline & 2016 & 2017 & 2016 & 2017 & 2016 & 2017 & 2016 & 2017 & 2016 & 2017 & 2016 & 2017 & 2016 & 2017 & 2016 & 2017 \\
\hline N1 & $35.1 \mathrm{a}$ & $45.1 b$ & $33.3 a$ & $33.8 \mathrm{a}$ & $26.8 \mathrm{a}$ & $20.3 a$ & $21.7 \mathrm{a}$ & $51.1 \mathrm{a}$ & $38.1 \mathrm{a}$ & $34.6 \mathrm{a}$ & $45.0 \mathrm{~b}$ & $15.1 c$ & $34.2 \mathrm{a}$ & $39.8 b$ & $25.6 \mathrm{a}$ & $35.4 \mathrm{a}$ \\
\hline N2 & $49.3 \mathrm{a}$ & $59.7 a$ & $30.5 a$ & $30.7 \mathrm{ab}$ & $23.8 b$ & $19.7 \mathrm{ab}$ & $24.5 \mathrm{a}$ & $45.7 \mathrm{~b}$ & $26.9 a$ & $20.6 a$ & $45.0 \mathrm{~b}$ & $23.6 \mathrm{~b}$ & $39.9 a$ & $45.2 \mathrm{ab}$ & $22.4 \mathrm{~b}$ & $31.4 \mathrm{~b}$ \\
\hline N3 & $50.3 \mathrm{a}$ & $62.1 \mathrm{a}$ & $14.1 \mathrm{~b}$ & $25.2 b$ & $23.0 \mathrm{~b}$ & $18.8 \mathrm{c}$ & $11.9 b$ & $21.0 \mathrm{c}$ & $26.7 a$ & $19.1 \mathrm{a}$ & $74.0 \mathrm{a}$ & $53.8 \mathrm{a}$ & $32.2 \mathrm{a}$ & $43.6 a b$ & $17.5 \mathrm{c}$ & $20.7 c$ \\
\hline N4 & $47.8 \mathrm{a}$ & $65.7 \mathrm{a}$ & $16.1 b$ & $28.0 \mathrm{ab}$ & $22.8 b$ & $19.4 \mathrm{bc}$ & $14.1 \mathrm{~b}$ & $20.9 c$ & $29.4 a$ & $14.9 \mathrm{a}$ & $69.8 \mathrm{a}$ & $51.1 \mathrm{a}$ & $32.0 \mathrm{a}$ & $46.9 a$ & $18.4 \mathrm{c}$ & $20.1 c$ \\
\hline
\end{tabular}

Different letters within a column represent significant differences $(p<0.05)$. 


\subsection{Distribution of Residual ${ }^{15} \mathrm{~N}$ in Soil}

The distribution of residual ${ }^{15} \mathrm{~N}$ in the upper $0-60 \mathrm{~cm}$ of soil was analyzed and presented in Figure 2. After the wheat harvest, in the 2016 and 2017 growing seasons, the total residual ${ }^{15} \mathrm{~N}$ in the upper $0-60 \mathrm{~cm}$ accounted for $22.8-26.8 \%$ and $18.8-20.3 \%$ of ${ }^{15} \mathrm{~N}$, respectively. In 2016 , after wheat was fertilized basally, half of the residual ${ }^{15} \mathrm{~N}$ remained in the upper $0-20 \mathrm{~cm}$ of soil and $\mathrm{N} 1 \mathrm{was}$ significantly different from the other treatments (Figure 2A). Treatment N1 had the highest residual ${ }^{15} \mathrm{~N}$ when $\mathrm{N}$ was applied traditionally $\left(210 \mathrm{~kg} \mathrm{~N} \mathrm{ha}^{-1}\right)$. In the $20-40 \mathrm{~cm}$ and $40-60 \mathrm{~cm}$ soil layers, there was no difference between N1 and N2 or N3. However, applying $\mathrm{N}$ to wheat by topdressing showed that residual ${ }^{15} \mathrm{~N}$ was affected by application time compared with that of $\mathrm{N} 1$ (Figure 2B). Although in treatment $\mathrm{N} 1$, more $\mathrm{N}$ was applied than in the other treatments, its residual ${ }^{15} \mathrm{~N}$ did not differ from that of the other treatments in the upper $60 \mathrm{~cm}$ of soil. In 2017 , the residual ${ }^{15} \mathrm{~N}$ distribution in the upper $60 \mathrm{~cm}$ of soil was similar to that in 2016 (Figure 2C,D). The above results indicated that the topdressing fertilizer is better at the jointing stage than at the wintering stage. It can reduce the residual $\mathrm{N}$ in the soil after the wheat harvest.
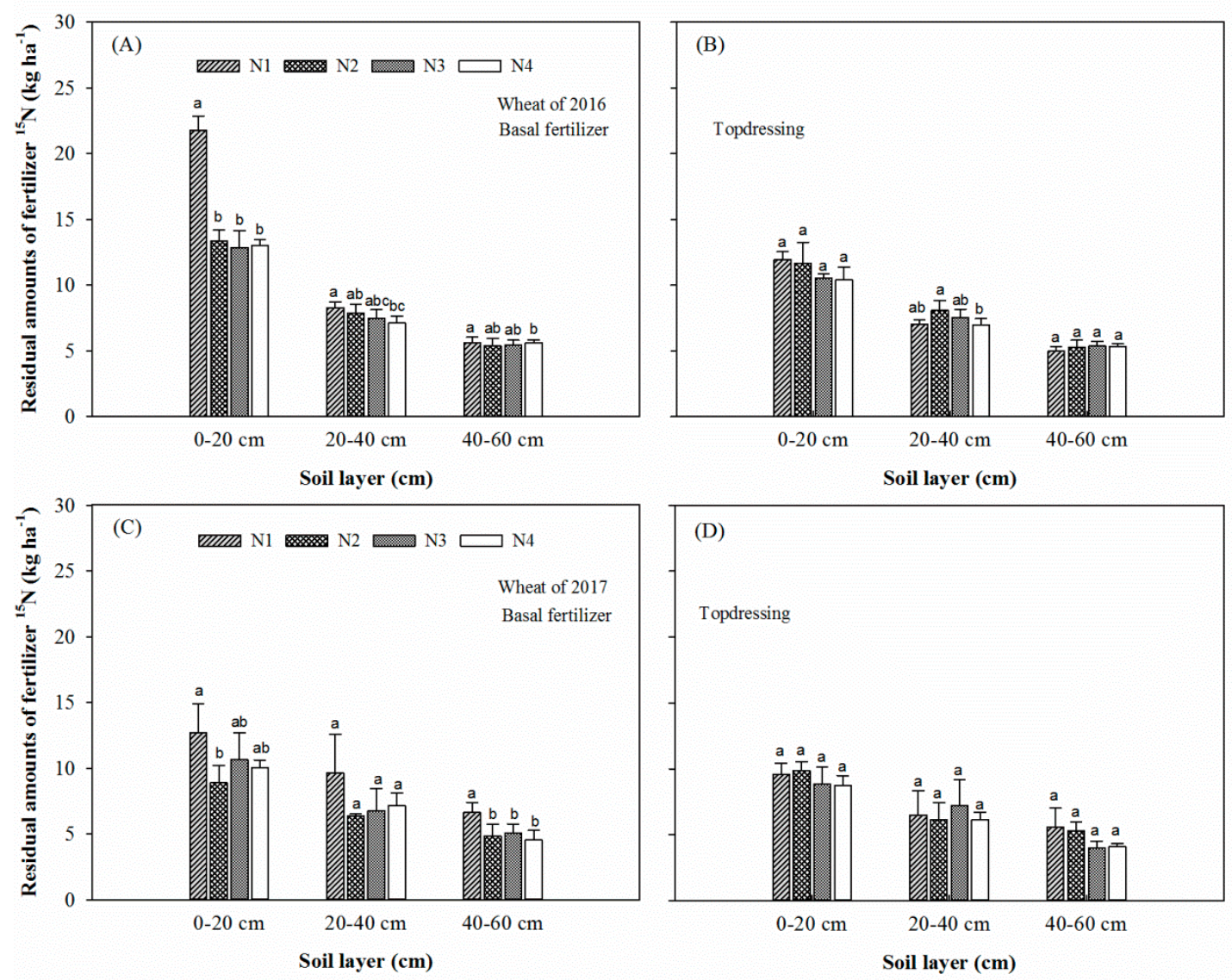

Figure 2. Effect of nitrogen management on the distribution of residual ${ }^{15} \mathrm{~N}$ in $0-60 \mathrm{~cm}$ soil profiles from basal ((A,C): basal fertilizer of wheat) and topdressed ((B,D): topdressed fertilizer of wheat) $\mathrm{N}$ in 2016 and 2017 after wheat harvest. The vertical bar indicates the standard error of the mean. Different letters represent significant differences $(p<0.05)$.

After the maize harvest, the residual ${ }^{15} \mathrm{~N}$ in soil was significantly different among treatments. Under different $\mathrm{N}$ management practices, the distribution characteristics in both years and in different soil profile layers were similar (Figure $3 \mathrm{~A}, \mathrm{~B}$ ). The residual ${ }^{15} \mathrm{~N}$ was mainly concentrated in the topsoil and was highest for N1, then N2. There was no difference between treatments N3 and N4 and the amount of residual ${ }^{15} \mathrm{~N}$ was lower. The results revealed that the amount of residual ${ }^{15} \mathrm{~N}$ decreased with lower $\mathrm{N}$ application rates. Furthermore, the application of slow-release fertilizer and its combination 
with urea were also important to reduce residual $\mathrm{N}$ in the soil. Since the $\mathrm{N}$ management is based on annual rotation, the annual residual ${ }^{15} \mathrm{~N}$ exposed that the treatments with reduced $\mathrm{N}$ application rate had lower residual ${ }^{15} \mathrm{~N}$ compared to that of treatment $\mathrm{N} 1$ in the top $60 \mathrm{~cm}$ of soil (Figure 3C,D). Additionally, applying the fertilizer three times is beneficial for reducing the residual $\mathrm{N}$ of the soil after the crop is harvested in a rotation system compared to that of traditional $\mathrm{N}$ practice.
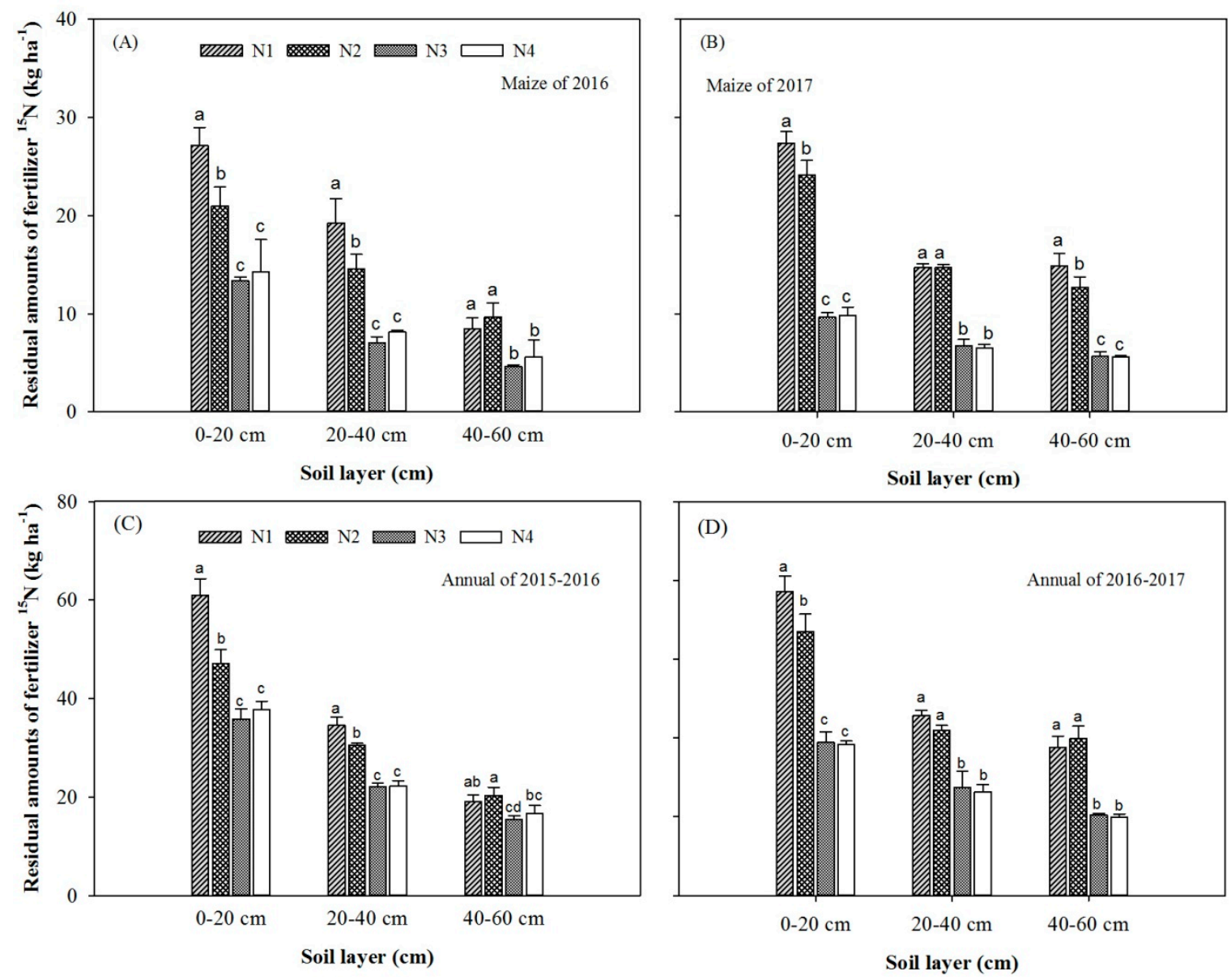

Figure 3. Effect of nitrogen management on the distribution of residual ${ }^{15} \mathrm{~N}$ after maize harvest ((A,B): residual $\mathrm{N}$ of maize) and annual residual ${ }^{15} \mathrm{~N}((\mathbf{C}, \mathbf{D})$ : annual residual of wheat and maize) in $0-60 \mathrm{~cm}$ soil profiles in 2016 and 2017. The vertical bar indicates the standard error of the mean. Different letters represent significant differences $(p<0.05)$.

\section{Discussion}

\subsection{Effect of N Management on N Uptake and Grain Yield}

Many studies have reported that optimizing $\mathrm{N}$ management by reducing the rate of application of $\mathrm{N}$ and adjusting the ratio of basal to topdressing $\mathrm{N}$ can enhance crop yield, plant $\mathrm{N}$ uptake, and NRE and reduce residual $\mathrm{N}$ in the soil $[11,34,35]$. In the present study, reducing the $\mathrm{N}$ application rate did not affect the grain yield or total $\mathrm{N}$ uptake of wheat and maize compared to that in traditional $\mathrm{N}$ application practice; in a previous study, similar results were obtained by Wang et al. and Jia et al. [11,36]. The reason may be ascribed to the relatively high $\mathrm{N}$ fertility (total $\mathrm{N} 1.54 \mathrm{~g} \mathrm{~kg}^{-1}$ ) of soil environmental $\mathrm{N}$ inputs. Fang et al. [37] showed that reducing $\mathrm{N}$ fertilizer rates to about $100-200 \mathrm{~kg} \mathrm{~N}^{-1}$ did not deplete $\mathrm{NO}_{3}{ }^{-} \mathrm{N}$ content in $0-100 \mathrm{~cm}$ soil layer and maintained stable grain yield. Other researchers found that the $\mathrm{N}$ application rate did not affect the plant $\mathrm{N}$ derived from soil $[26,36]$ which means a lower $\mathrm{N}$ application rate in a continuous wheat-maize double cropping system may cause soil $\mathrm{N}$ depletion. Our results also found that soil-derived $\mathrm{N}$ was more than one-second and two-thirds of 
the $\mathrm{N}$ assimilated by wheat and maize, respectively (Table 5). In the wheat-maize rotation system, annual $\mathrm{N}$ management did not affect wheat's NRE but greatly affected the NRE of maize. In the maize growing season, when reducing the application rate of $\mathrm{N}$, applying $\mathrm{N}$ at the jointing and bell stage (N2) performed better than other treatments in terms of improving the NRE. This may be because when basal $\mathrm{N}$ was applied before planting, it can easily be leached out to below the rooting zone when the crop has a limited root system for $\mathrm{N}$ uptake; in addition, the higher temperatures accelerate the decomposition of urea [38]. Furthermore, applying SRF at the ratio of 1:1 with urea as the sole source of $\mathrm{N}$ in the growing season of maize also did not sacrifice the grain yield. This result was closely related to the release characteristic of SRF and consistent with those of Geng et al. [39]. Some studies have reported that the protein content responded positively at the highest $\mathrm{N}$ rate, whereas at lower $\mathrm{N}$ rates, no significant difference was observed. In the present study, under the optimized $\mathrm{N}$ rate, our results are in accordance with those of Cucci and Lacolla [40], and Dostálová et al. [41].

\subsection{N Efficiency in the Plant-Soil System}

The different $\mathrm{N}$ managements significantly affected NRE, soil $\mathrm{N}$ residual and $\mathrm{N}$ losses of wheat and maize. Compared to traditional $\mathrm{N}$ practice, reducing the $\mathrm{N}$ application rate did not affect the NRE of wheat and annual NRE in 2016. But the NRE was significantly higher than N1 in 2017. For maize, the NRE in N3 and N4 decreased with one N application compared to split N in N1 and N2. The residual $\mathrm{N}$ in wheat and maize growing seasons were within the range of $20.9-23.6 \%$ and $16.4-36.4 \%$ (mean of two years), respectively. the $\mathrm{N}$ losses in wheat were in the range of $22.2-36.4 \%$. The highest $\mathrm{N}$ losses were in N3 and N4 $(60.45,63.9 \%)$ in maize growing seasons, which were significantly higher than N1 and N2 (Table 7). As for topdressing fertilizer, applying $\mathrm{N}$ at the jointing stage of wheat increased the REN and the annual NRE was also improved. For maize, applying $\mathrm{N}$ at the jointing stage and bell stage may be attributed to better synchronization between $\mathrm{N}$ supply and crop demand compared to one application. The $\mathrm{N}$ uptake in $\mathrm{N} 0$ and the fate of ${ }^{15} \mathrm{~N}$-labeled urea indicated the high inorganic $\mathrm{N}$ concentration in the soil profile. At the $\mathrm{N}$ rate of $210 \mathrm{~kg} \mathrm{ha}^{-1}$, total plant $\mathrm{N}$ derived from the fertilizer of wheat was in the range of $114.5-119.2 \mathrm{~kg} \mathrm{ha}^{-1}$ (mean of two years). An average of $92.8 \mathrm{~kg} \mathrm{ha}^{-1}$ fertilizer $\mathrm{N}$ lost to the environment, which included $19.7 \mathrm{~kg} \mathrm{ha}^{-1}$ residual $\mathrm{N}$ remained in the soil and $73.1 \mathrm{~kg} \mathrm{ha}^{-1} \mathrm{~N}$ lost by gaseous losses. For maize, total plant $\mathrm{N}$ derived from fertilizer was only $41.2-64.3 \mathrm{~kg} \mathrm{ha}^{-1}$ (mean of two years), An average of $159.4 \mathrm{~kg} \mathrm{ha}^{-1}$ fertilizer could be saved in the maize growing season, including $35.8 \mathrm{~kg} \mathrm{ha}^{-1}$ residual $\mathrm{N}$ and $123.5 \mathrm{~kg} \mathrm{ha}^{-1}$ gaseous $\mathrm{N}$. Therefore, the $\mathrm{N}$ losses in this two ways accounted for at least $50 \%$ among the treatments. The fertilizer $\mathrm{N}$ application could be cut in half without crop yield reduction for two annual rotation years.

\subsection{Fate of ${ }^{15} \mathrm{~N}$-Labeled Urea Affected by $\mathrm{N}$ Management}

Application practice affected the utilization of $\mathrm{N}$ from fertilizer and soil by the crop. To monitor the $\mathrm{N}$ dynamics in plant and soil during the growth seasons of the crop, the fate of ${ }^{15} \mathrm{~N}$-labeled urea was investigated. In this study, for wheat, the ${ }^{15} \mathrm{~N}$-labeled urea derived from fertilizer and soil in straw and grain was not significantly different among the treatments for the two years. For maize, the total $\mathrm{N}$ uptake consisted of $12.85-26.05 \%$ (mean of two years) of fertilizer ${ }^{15} \mathrm{~N}$ and $73.95-87.15 \%$ (mean of two years) of soil $\mathrm{N}$, respectively. In the wheat growth season, the $\mathrm{N}$ derived from fertilizer did not differ compared with $\mathrm{N} 1$ when reducing the $\mathrm{N}$ application rate. In the growth season of maize, reducing the $\mathrm{N}$ application rate decreased the plant's $\mathrm{N}$ from fertilizer, but more $\mathrm{N}$ from the soil was absorbed compared to that in N1 (Tables 5 and 6). These results are similar to those in earlier studies of Rimski-Korsakov et al. [42] and Wang et al. [34], who studied different $\mathrm{N}$ split application to plastic mulched maize and this suggests that the majority of the crop's $\mathrm{N}$ comes from $\mathrm{N}$ mineralization of soil organic matter and not directly from fertilizer. Other studies also reported that the $\mathrm{N}$ in the crop absorbed by mineralization of the soil organic matter can account for $62-80 \%$ of the total $\mathrm{N}$ in cereal crops $[28,43]$. In the present study, optimized $\mathrm{N}$ use could reduce the annual $\mathrm{N}$ fertilization rate and improve $\mathrm{N}$ uptake from soil especially for maize, which is beneficial to the environment. 
It is generally believed that $\mathrm{N}$ losses inevitably occur when large amounts of $\mathrm{N}$ fertilizer are applied to the soil, especially on farmers' fields. In this study, the potential losses after the wheat harvested were not different among treatments in either year, but the $\mathrm{N}$ losses in N1 were higher than in the other treatments (Table 7). This indicated that integrated $\mathrm{N}$ treatment, with its reducing $\mathrm{N}$ application rate, results in lower $\mathrm{N}$ losses than in $\mathrm{N} 1$, without a corresponding decrease in grain yield. Furthermore, in the growth seasons of wheat, the $\mathrm{N}$ losses in integrated $\mathrm{N}$ treatments were relatively lower, ranging from $22.2 \%$ to $23.8 \%$ (mean of two years). $\mathrm{N}$ losses were lower than in other reports that studied the maize and rice system, such as Shi et al. [44] and Wang et al. [28]. Our results also found that the $\mathrm{N}$ losses for the summer maize season were significantly higher than the winter wheat season. This result was also similar to that of Cai et al. and Wang et al. [29,45]. This may be due to the lower $\mathrm{NH}_{3}$ volatilization and $\mathrm{N}$ leaching losses, which depend on the weather conditions (precipitation/irrigation and air temperature) and soil moisture (Figure 1). However, the losses of ${ }^{15} \mathrm{~N}$-labeled fertilizer during the maize season accounted for 63.9 and $60.5 \%$ (mean of two years) in treatments N3 and N4, respectively, and were significantly higher than in N1 and N2. During the growth season of maize, the temperature was high and rainfall was relatively low, especially in August, which led to lower soil moisture levels. Therefore, leaching losses is not a significant pathway for $\mathrm{N}$ loss from fertilizer in maize [45]. Other studies have already reported that the lower seasonal rainfall resulted in less soil water flux and less leaching losses $[38,46]$. The higher potential losses for N3 and $\mathrm{N} 4$ in maize were mainly ascribed to gaseous $\mathrm{N}$ emissions to the atmosphere. Regarding this, $\mathrm{N}_{2} \mathrm{O}$ emission, although subjected to fertilizer management, accounts only for a very little part of the total $\mathrm{N}$ applied. The IPCC [47] established that $1.25 \pm 1.0 \%$ of the fertilizer $\mathrm{N}$ applied is lost to the atmosphere in the form of $\mathrm{N}_{2} \mathrm{O}$. Thus, in this study, gaseous $\mathrm{N}$ losses by $\mathrm{NH}_{3}$ volatilization may have reflected the actual losses more closely since the fertilizer (SRF or urea) was applied at a depth of $10 \mathrm{~cm}$ and covered with soil. Other studies indicated that the best measure to obtain higher $\mathrm{N}$ use efficiency and reduce $\mathrm{N}$ losses is by placing fertilizer at $15-20 \mathrm{~cm}$ depth, especially when using slow-release urea in the growing season of maize $[13,45,48]$. Moreover, it is well known that another important factor governing the $\mathrm{NH}_{3}$ volatilization is ammonical $\mathrm{N}$ concentration [49,50]. In our study, a possible reason for higher gaseous $\mathrm{N}$ losses was that the ammonical $\mathrm{N}$ concentration was substantially higher when fertilizer was applied once in N3 and N4 treatments in maize compared to that of treatments N1 and N2. An amount of SRF applied equivalent to the traditional urea rate of $\mathrm{N}$ did not reduce the $\mathrm{N}$ losses, which may due to the sustainable release of $\mathrm{N}$ supplied by SRF leads to a higher $\mathrm{N}$ content in topsoil compared to that of treatment $\mathrm{N} 1$ and N2. Wang et al. [29] reported that $\mathrm{NO}_{3}{ }^{-}-\mathrm{N}$ content, temperature, and soil moisture had a significant positive influence on denitrification losses. In this study, the denitrification losses occurred for summer maize due to the higher $\mathrm{N}$ content and high temperature. Xie et al. [51] found that a $10 \%$ reduction of application SRF led to lower $\mathrm{N}_{2} \mathrm{O}$ emissions. Lower $\mathrm{N}$ losses were obtained when $\mathrm{N}$ fertilizer application was divided into an appropriate ratio of basal and topdressing N. In this case, though fertilizer applied once in maize can reduce labor input, $\mathrm{N}$ loss was higher compared to split fertilization.

The soil residual of the ${ }^{15} \mathrm{~N}$-labeled fertilizer at wheat and maize harvest was calculated in the upper layer of $0-60 \mathrm{~cm}$. In the present study, the $\mathrm{N}$ application rate affected the amount of residual in the soil significantly. The residual in N1 was obviously higher than in other treatments and reducing the application rate of $\mathrm{N}$ can significantly decrease the soil residual (Figure 2, Figure 3 and Table 7). Similar results were reported by Liu et al. [52]. For wheat, $\mathrm{N}$ topdressing had no effect on the $\mathrm{N}$ residual of the soil. While in the case of maize, the fertilizer management obviously influenced the soil N residual. In N3 and N4 treatments, using SRF only or in combination with urea at a ratio of 1:1 can decrease the amount of $\mathrm{N}$ residual, but increased the $\mathrm{N}$ losses compared to $\mathrm{N} 2$. This was due to the split $\mathrm{N}$ application (N2) being more optimal than one-off fertilization (N4). In the maize growing season, using SRF once in N3 and N4 saved labor and time and increased the economic benefits [6], but the NRE was lower than the split $\mathrm{N}$ application. Regarding the annual $\mathrm{N}$ residual, treatment $\mathrm{N} 1$ was highest, then $\mathrm{N} 2$, and N3 and N4 were lowest. The annual residual ${ }^{15} \mathrm{~N}$ in the upper $60 \mathrm{~cm}$ 
soil layer ranged from $17.5 \%$ to $25.6 \%$ in 2016 and from $20.1 \%$ to $35.4 \%$ in 2017 . This was consistent with the report of Shi et al. [44], who found the soil residual in the upper $100 \mathrm{~cm}$ of the Middle and Lower Yangtze River Basin to account for just 33\%. The lower residual $\mathrm{N}$ in the present study may be attributed to the higher gaseous losses during the growing season of maize.

To sum up, in terms of wheat and maize grain yields, NRE, residual $\mathrm{N}$ of the soil, and $\mathrm{N}$ losses in an intensive wheat-maize rotation system, the $\mathrm{N}$ rate in the present study was $210 \mathrm{~kg} \mathrm{ha}^{-1}$ per plant (annual N $\left.420 \mathrm{~kg} \mathrm{ha}^{-1}\right)$. This $\mathrm{N}$ rate was similar to the optimum application rate $\left(200 \mathrm{~kg} \mathrm{ha}^{-1}\right.$, $202 \mathrm{~kg} \mathrm{ha}^{-1}, 210 \mathrm{~kg} \mathrm{ha}^{-1}$ ) reported by Fang et al., Zhang et al., and Jia et al. [36,37,53], but higher than other results $\left(150\right.$ or $120 \mathrm{~kg} \mathrm{ha}^{-1}$ ) [54,55]. In the present study, the $\mathrm{N}$ uptake of the plant was $129.3-186.2 \mathrm{~kg} \mathrm{ha}^{-1}$ in N0 treatment. Under the different $\mathrm{N}$ treatments of two years, the $\mathrm{N}$ uptake of wheat that derived from fertilizer was within the range of $94.8-105.6 \mathrm{~kg} \mathrm{ha}^{-1}$ and $121.7-138.0 \mathrm{~kg} \mathrm{ha}^{-1}$, and $128.5-152.5 \mathrm{~kg} \mathrm{ha}^{-1}$ and $204.1-228.6 \mathrm{~kg} \mathrm{ha}^{-1}$ that was derived from the soil, respectively. The fate of ${ }^{15} \mathrm{~N}$ labeled-urea demonstrated that $57.5-63.6 \% \mathrm{~N}$ accumulated in the wheat plant and $69.7-88.1 \%$ in maize was derived from soil, respectively. These results indicated that the $\mathrm{N}$ uptake in the present study was higher with high soil mineralization. Sufficient $\mathrm{N}$ supply in soil enhanced $\mathrm{N}$ uptake by the plant from the soil. Some works have already reported that crop yield response to applied $\mathrm{N}$ was strongly affected by soil $\mathrm{N}$ supply [56,57]. Olson et al. [57] found that if soil profile inorganic $\mathrm{N}$ exceeded $120 \mathrm{~kg} \mathrm{ha}^{-1}$, the crop yield had no response to added $\mathrm{N}$. A second reason is the large amount of nitrate- $\mathrm{N}$ accumulated in the root zone and severe leaching did not occur since the rainfall was lower in the crop growing season. Furthermore, it may also be related to the differences of $\mathrm{N}$ nutrition characteristics among different genotypes of wheat. Thus, the $210 \mathrm{~kg} \mathrm{ha}^{-1}$ application rate was still high under high fertility conditions. The current $\mathrm{N}$ managements were relatively effective in improving NRE, soil's $\mathrm{N}$ residual and $\mathrm{N}$ losses, but they were not optimal fertilization management. Zhao and $\mathrm{Yu}$ [58] reported that under high fertility soil, at the mature stage of wheat, $73.3-87.3 \% \mathrm{~N}$ uptake was derived from soil and $34.2-43.7 \%$ from $\mathrm{N}$ fertilizer applied. The $\mathrm{N}$ rate in the range of 150-195 $\mathrm{kg} \mathrm{ha}^{-1}$ was beneficial to crop yield, NRE, and environment. Similar results had been reported by Wang et al. [34] and Chen et al. [59]. Another study showed that under the conditions of high fertilization for many years, the soil $\mathrm{N}$ supply was sufficient to match the crop needs even without fertilization [60]. These researches were in agreement with the present study as described above. Apparently, the optimal $\mathrm{N}$ rate should be determined by crop yield potential and background soil fertility, especially the available $\mathrm{N}$ content in the soil and fertilizer-holding capacity of the soil. Based on present $\mathrm{N}$ treatments, we recommend that decreasing $\mathrm{N}$ rate by $40 \%$ for winter wheat with split $\mathrm{N}$ at the basal and jointing stage, and for summer maize, reducing the $\mathrm{N}$ rate by $50 \%$ with two topdressing $\mathrm{N}$ at the jointing and bell stage may be a more efficient strategy to enhance NRE and reduce $\mathrm{N}$ losses to the environment. Further studies are still needed to determine optimum N management practice in the long term based on the soil $\mathrm{N}_{\min }$ test, which can be applied in the winter wheat-summer maize rotation system in the North China Plain.

\section{Conclusions}

In general, compared with the conventional practice of $\mathrm{N}$ fertilization, reducing the application rate of $\mathrm{N}$ did not affect the yield of wheat and maize in both rotation years. Optimized annual $\mathrm{N}$ management does not affect the total $\mathrm{N}$ uptake by the plant but affected the proportion of $\mathrm{N}$ uptake that derived from fertilizer and soil. It can induce plants to absorb more $\mathrm{N}$ from the soil, especially maize. The NRE did not differ significantly with annual $\mathrm{N}$ management. Moreover, the residual $\mathrm{N}$ in the soil can be reduced by reducing the $\mathrm{N}$ application rate. The potential losses in wheat were not significantly different among treatments, but maize N3 and N4 had higher potential losses. Considering the large amount of labor involved in topdressing, N3 and N4 are better solutions for farmers using the wheat-maize double system when placing fertilizer at a depth of $15 \mathrm{~cm}$. When SRF is too expensive for farmers, and minimizing environmental pollution from $\mathrm{NH}_{3}$ volatilization and denitrification losses, $\mathrm{N} 2$ is also an alternative choice. However, the continuous reduction of $\mathrm{N}$ fertilizer may reduce soil 
fertility in the long term. Therefore, these strategies are suitable for at least two years of wheat-maize rotation production and it remains to be determined for several successive years.

Author Contributions: Data curation, H.L., P.S., X.K., Y.L. (Yuncheng Liao), Y.L. (Yang Liu) and X.W.; formal analysis, H.L. and Y.L. (Yang Liu); funding acquisition, Y.L. (Yuncheng Liao); investigation, H.L. and X.K.; methodology, Y.L. (Yang Liu); project administration, Y.L. (Yuncheng Liao); supervision, Y.L. (Yuncheng Liao), Y.L. (Yang Liu) and X.W.; writing-original draft, H.L.; writing-review \& editing, H.L., Y.L. (Yang Liu) and X.W. All authors have read and agreed to the published version of the manuscript.

Funding: This research was funded by Special Project for Agro-scientific Research in the Public Interest: 201503121-09. Projects of International Cooperation and Exchanges: 31761143003.

Acknowledgments: This research was financially supported by Special Project for Agro-scientific Research in the Public Interest (201503121-09), Projects of International Cooperation and Exchanges (31761143003).

Conflicts of Interest: The authors declare no conflict of interest.

\section{References}

1. Heffer, P. Assessment of Fertilizer Use by Crop at the Global Level; International Fertilizer Industry Association: Paris, France, 2009.

2. Meng, Q.F.; Yue, S.C.; Hou, P.; Cui, Z.L.; Chen, X.P. Improving Yield and Nitrogen Use Efficiency Simultaneously for Maize and Wheat in China: A Review. Pedosphere 2016, 26, 137-147. [CrossRef]

3. Zhang, S.L.; Gao, P.C.; Tong, Y.N.; Norse, D.; Lu, Y.L.; Powlson, D. Overcoming nitrogen fertilizer over-use through technical and advisory approaches: A case study from Shaanxi Province, northwest China. Agric. Ecosyst. Environ. 2015, 209, 89-99. [CrossRef]

4. Cui, Z.L.; Chen, X.P.; Zhang, F.S. Current Nitrogen Management Status and Measures to Improve the Intensive Wheat-Maize System in China. Ambio 2010, 39, 376-384. [CrossRef] [PubMed]

5. World Bank (2016) Fertilizer Consumption. Available online: http://data.worldbank.org/indicator/AG.CON . FERT.ZS?locations=CN (accessed on 10 April 2017).

6. $\quad$ Liang, H.Y.; Zhang, X.L.; Han, J.; Liao, Y.C.; Liu, Y.; Wen, X.X. Integrated N management improves nitrogen use efficiency and economics in a winter wheat-summer maize multiple-cropping system. Nutr. Cycl. Agroecosyst. 2019, 115, 313-329. [CrossRef]

7. Chen, X.; Zhang, F.; Römheld, V.; Horlacher, D.; Schulz, R.; Böning-Zilkens, M.; Wang, P.; Claupein, W. Synchronizing N Supply from Soil and Fertilizer and N Demand of Winter Wheat by an Improved Nmin Method. Nutr. Cycl. Agroecosyst. 2006, 74, 91-98. [CrossRef]

8. Tilman, D.; Cassman, K.G.; Matson, P.A.; Naylor, R.; Polasky, S. Agricultural sustainability and intensive production practices. Nature 2002, 418, 671-678. [CrossRef] [PubMed]

9. Chen, X.; Ma, L.; Ma, W.; Wu, Z.; Cui, Z.; Hou, Y.; Zhang, F. What has caused the use of fertilizers to skyrocket in China. Nutr. Cycl. Agroecosyst. 2018, 110, 241-255. [CrossRef]

10. Raun, W.R.; Johnson, G.V. Improving Nitrogen Use Efficiency for Cereal Production. Agron. J. 1999, 91, $357-363$. [CrossRef]

11. Wang, G.L.; Ye, Y.L.; Chen, X.P.; Cui, Z.L. Determining the optimal nitrogen rate for summer maize in China by integrating agronomic, economic, and environmental aspects. Biogeosciences 2014, 11, 3031-3041. [CrossRef]

12. Reay, D.S.; Davidson, E.A.; Smith, K.A.; Smith, P.; Melillo, J.M.; Dentener, F.; Crutzen, P.J. Global agriculture and nitrous oxide emissions. Nat. Clim. Chang. 2012, 2, 410-416. [CrossRef]

13. Wu, M.; Li, G.L.; Li, W.T.; Liu, J.; Liu, M.; Jiang, C.Y.; Li, Z.P. Nitrogen Fertilizer Deep Placement for Increased Grain Yield and Nitrogen Recovery Efficiency in Rice Grown in Subtropical China. Front. Plant Sci. 2017, 8, 1227. [CrossRef] [PubMed]

14. Seo, J.H.; Cho, H.S.; Kim, C.G.; Lee, J.M.; Choi, S.H. Yield and Nitrogen Uptake under Reduced Nitrogen Fertilizer during Early Growth of Rice in the Rice-Barley Double Cropping System. Korean J. Crop Sci. 2004, 49, 1-6.

15. Yang, X.; Lu, Y.; Ding, Y.; Yin, X.; Raza, S.; Tong, Y.A. Optimising nitrogen fertilisation: A key to improving nitrogen-use efficiency and minimising nitrate leaching losses in an intensive wheat/maize rotation (2008-2014). Field Crop Res. 2017, 206, 1-10. [CrossRef] 
16. Liu, X.J.; Ju, X.T.; Zhang, F.S. Effect of reduced $\mathrm{N}$ application on $\mathrm{N}$ utilization and balance in winter wheat-summer maize cropping system. J. Appl. Ecol. 2004, 15, 458-462.

17. Ju, X.T.; Xing, G.X.; Chen, X.P.; Zhang, S.L.; Zhang, L.J.; Liu, X.J.; Cui, Z.L.; Yin, B.; Christiea, P.; Zhu, Z.L.; et al. Reducing environmental risk by improving $\mathrm{N}$ management in intensive Chinese agricultural systems. Proc. Natl. Acad. Sci. USA 2009, 106, 3041-3046. [CrossRef]

18. Guo, J.H.; Liu, X.J.; Zhang, Y.; Shen, J.L.; Han, W.X.; Zhang, W.F.; Christie, P.; Goulding, K.W.T.; Vitousek, P.M.; Zhang, F.S. Significant acidification in major Chinese croplands. Science 2010, 327, 1008-1010. [CrossRef]

19. Yao, Y.L.; Zhang, M.; Tian, Y.H.; Zhao, M.; Zhang, B.W.; Zeng, K.; Yin, B. Urea deep placement in combination with Azolla for reducing nitrogen loss and improving fertilizer nitrogen recovery in rice field. Field Crop Res. 2018, 218, 141-149. [CrossRef]

20. Zheng, W.K.; Zhang, M.; Liu, Z.G.; Zhou, H.Y.; Lu, H.; Zhang, W.T.; Yang, Y.C.; Li, C.L.; Chen, B.C. Combining controlled-release urea and normal urea to improve the nitrogen use efficiency and yield under wheat-maize double cropping system. Field Crop Res. 2016, 197, 52-62. [CrossRef]

21. Zhao, X.; Xie, Y.X.; Xiong, Z.Q.; Yan, X.Y.; Xing, G.X.; Zhu, Z.L. Nitrogen fate and environmental consequence in paddy soil under rice-wheat rotation in the Taihu lake region, China. Plant Soil 2009, 319, $225-234$. [CrossRef]

22. Song, C.; Guan, Y.; Wang, D.; Zewudie, D.; Li, F.M. Palygorskite-coated fertilizers with a timely release of nutrients increase potato productivity in a rain-fed cropland. Field Crop Res. 2014, 166, 10-17. [CrossRef]

23. Geng, J.B.; Sun, Y.B.; Zhang, M.; Li, C.L.; Yang, Y.C.; Liu, Z.G.; Li, S.L. Long-term effects of controlled release urea application on crop yields and soil fertility under rice-oilseed rape rotation system. Field Crop Res. 2015, 184, 65-73. [CrossRef]

24. Lopez-Bellido, L.; Lopez-Bellido, R.J.; Redondo, R. Nitrogen efficiency in wheat under rainfed Mediterranean conditions as affected by split nitrogen application. Field Crop Res. 2005, 94, 86-97. [CrossRef]

25. Cui, Z.L.; Zhang, F.S.; Chen, X.P.; Miao, Y.X.; Li, J.L.; Shi, L.W.; Xu, J.F.; Youliang, Y.L.; Liu, C.S.; Yang, Z.P.; et al. On-farm evaluation of an in-season nitrogen management strategy based on soil N-min test. Field Crop Res. 2008, 105, 48-55. [CrossRef]

26. Chen, Z.; Wang, H.; Liu, X.; Lu, D.; Zhou, J. The fates of N-15-labeled fertilizer in a wheat-soil system as influenced by fertilization practice in a loamy soil. Sci. Rep. 2016, 6, 34754. [CrossRef] [PubMed]

27. Stevens, W.B.; Hoeft, R.G.; Mulvaney, R.L. Fate of Nitrogen-15 in a Long-Term Nitrogen Rate Study. Agron. J. 2005, 97, 1046. [CrossRef]

28. Wang, X.T.; Suo, Y.Y.; Feng, Y.; Shohag, M.J.I.; Gao, J.; Zhang, Q.C.; Xie, S.; Lin, X.Y. Recovery of N-15-labeled urea and soil nitrogen dynamics as affected by irrigation management and nitrogen application rate in a double rice cropping system. Plant Soil 2011, 343, 195-208. [CrossRef]

29. Wang, X.B.; Zhou, W.; Liang, G.Q.; Pei, X.X.; Li, K.J. The fate of N-15-labelled urea in an alkaline calcareous soil under different $\mathrm{N}$ application rates and N splits. Nutr. Cycl. Agroecosyst. 2016, 106, 311-324. [CrossRef]

30. Liu, G.; Wan, L.B.; Zhang, M.; Cao, Y.P.; Xu, Q.M.; Chen, H.K.; Yang, Y.C. State Standard of the People's Republic of China-Slow Release Fertilizer (GB/T 23348-2009); China Standard Press: Beijing, China, 2009; pp. 2-5. (In Chinese)

31. Xu, L.; Xing, L.T.; Wang, X.; Li, Z.P.; Mao, J.L. Study on the Optimal Reaction Temperature and Sampling Weight for Measurement of Carbon and Nitrogen Isotope Ratio by Elemental Analysis-Isotope Ratio Mass Spectrometer. Rock Miner. Anal. 2018, 37, 15-20. (In Chinese)

32. Halitligil, M.B.; Akın, A.; Bilgin, N.; Deniz, Y.; Ögretir, K.; Altınel, B.; Isık, Y. Effect of nitrogen fertilization on yield and nitrogen and water use efficiencies of winter wheat (durum and bread) varieties grown under conditions found in Central Anatolia. Biol. Fertil. Soils 2000, 31, 175-182. [CrossRef]

33. Yang, Y.M.; Wang, X.B.; Dai, K.; Jia, S.L.; Meng, C.X.; Zhao, Q.S.; Zhang, X.M.; Zhang, D.C.; Feng, Z.H.; Sun, Y.M.; et al. Fate of labeled urea-N-15 as basal and topdressing applications in an irrigated wheat-maize rotation system in North China plain: II summer maize. Nutr. Cycl. Agroecosyst. 2011, 90, 379-389. [CrossRef]

34. Wang, S.J.; Luo, S.S.; Yue, S.C.; Shen, Y.F.; Li, S.Q. Fate of N-15 fertilizer under different nitrogen split applications to plastic mulched maize in semiarid farmland. Nutr. Cycl. Agroecosyst. 2016, 105, 129-140. [CrossRef]

35. Li, P.C.; Dong, H.L.; Liu, A.Z.; Liu, J.R.; Sun, M.; Li, Y.B.; Liu, S.D.; Zhao, X.H.; Mao, S.C. Effects of Nitrogen Rate and Split Application Ratio on Nitrogen Use and Soil Nitrogen Balance in Cotton Fields. Pedosphere 2017, 27, 769-777. [CrossRef] 
36. Jia, S.L.; Wang, X.B.; Yang, Y.M.; Dai, K.; Meng, C.X.; Zhao, Q.S.; Zhang, X.M.; Zhang, D.C.; Feng, Z.H.; Sun, Y.M.; et al. Fate of labeled urea- ${ }^{15} \mathrm{~N}$ as basal and topdressing applications in an irrigated wheat-maize rotation system in North China Plain: I winter wheat. Nutr. Cycl. Agroecosyst. 2011, 90, 331-346. [CrossRef]

37. Fang, Q.X.; Yu, Q.; Wang, E.; Chen, Y.H.; Zhang, G.L.; Wang, J.; Li, L.H. Soil nitrate accumulation, leaching and crop nitrogen use as influenced by fertilization and irrigation in an intensive wheat-maize double cropping system in the North China Plain. Plant Soil 2006, 284, 335-350. [CrossRef]

38. Gehl, R.J.; Schmidt, J.P.; Stone, L.R.; Schlegel, A.J.; Clark, G.A. In situ measurements of nitrate leaching implicate poor nitrogen and irrigation management on sandy soils. J. Environ. Qual. 2005, 34, 2243-2254. [CrossRef]

39. Geng, J.B.; Chen, J.Q.; Sun, Y.B.; Zheng, W.K.; Tian, X.F.; Yang, Y.C.; Li, C.L.; Zhang, M. Controlled Release Urea Improved Nitrogen Use Efficiency and Yield of Wheat and Corn. Agron. J. 2016, 108, 1666-1673. [CrossRef]

40. Cucci, G.; Lacolla, G. Effects of Nitrogen, Phosphorus and Potassium Rates on Yield and Quality on Durum Wheat in a Two-year Rotation. Ital. J. Agron. 2007, 2, 47-53. [CrossRef]

41. Dostálová, Y.; Hřivna, L.; Kotková, B.; Burešová, I.; Janečková, M.; Šottníková, V. Effect of nitrogen and sulphur fertilization on the quality of barley protein. Plant Soil Environ. 2016, 61, 399-404. [CrossRef]

42. Rimski-Korsakov, H.; Rubio, G.; Lavado, R.S. Fate of the nitrogen from fertilizers in field-grown maize. Nutr. Cycl. Agroecosyst. 2012, 93, 253-263. [CrossRef]

43. Chen, X.; Tang, X.; Yang, S.M.; Wu, C.Y.; Wang, J.Y. Contributions of different N sources to crop N nutrition in a Chinese rice field. Pedosphere 2010, 20, 198-208. [CrossRef]

44. Shi, Z.; Jing, Q.; Cai, J.; Jiang, D.; Cao, W.; Dai, T. The fates of ${ }^{15} \mathrm{~N}$ fertilizer in relation to root distributions of winter wheat under different N splits. Eur. J. Agron. 2012, 40, 86-93. [CrossRef]

45. Cai, G.X.; Chen, D.L.; Ding, H.; Pacholski, A.; Fan, X.H.; Zhu, Z.L. Nitrogen losses from fertilizers applied to maize, wheat and rice in the North China Plain. Nutr. Cycl. Agroecosyst. 2002, 63, 187-195. [CrossRef]

46. Zeinali, E.; Soltani, A.; Galeshi, S.; Movahedi Naeeni, S.A.R. Estimates of nitrate leaching from wheat fields in Gorgan, of Iran. Res. J. Environ. Sci. 2009, 3, 645-655. [CrossRef]

47. IPCC. Nitrous oxide from agricultural soils and manure management. In Intergovernmental Panel on Climate Change for National Greenhouse Gas Inventoties; Chaper 4; OECD: Paris, France, 1996; pp. 1-125.

48. Guo, L.W.; Ning, T.Y.; Nie, L.P.; Li, Z.J.; Lal, R. Interaction of deep placed controlled-release urea and water retention agent on nitrogen and water use and maize yield. Eur. J. Agron. 2016, 75, 118-129. [CrossRef]

49. Ahmed, O.H.; Husin, A.; Hanif, A.H.M. Ammonia volatilization and ammonium accumulation from urea mixed with zeolite and triple superphosphate. Acta Agric. Scand. Sect. B Soil Plant Sci. 2008, 58, 182-186.

50. White, R.E.; Cai, G.; Chen, D.; Fan, X.H.; Pacholski, A.; Zhu, Z.L.; Ding, H. Gaseous nitrogen losses from urea applied to maize on a calcareous fluvo-aquic soil in the North China Plain. Soil Res. 2002, 40, 737. [CrossRef]

51. Xie, Y.; Tang, L.; Han, Y.; Yang, L.; Xie, G.; Peng, J.; Tian, C.; Zhou, X.; Liu, Q.; Rong, X.; et al. Reduction in nitrogen fertilizer applications by the use of polymer-coated urea: Effect on maize yields and environmental impacts of nitrogen losses. J. Sci. Food Agric. 2019, 99, 2259-2266. [CrossRef]

52. Liu, X.; Xu, S.S.; Zhang, J.W.; Ding, Y.F.; Li, G.H.; Wang, S.H.; Liu, Z.H.; Tang, S.; Ding, C.Q.; Chen, L. Effect of continuous reduction of nitrogen application to a rice-wheat rotation system in the middle-lower Yangtze River region (2013-2015). Field Crop Res. 2016, 196, 348-356. [CrossRef]

53. Zhang, Y.T.; Wang, H.Y.; Lei, Q.L.; Luo, J.F.; Lindsey, S.; Zhang, J.Z.; Zhai, L.M.; Wu, S.X.; Zhang, J.S.; Liu, X.X.; et al. Optimizing the nitrogen application rate for maize and wheat based on yield and environment on the Northern China Plain. Sci. Total Environ. 2018, 618, 1173-1183. [CrossRef]

54. Pan, J.R.; Ju, X.T.; Liu, X.J.; Chen, X.P.; Zhang, F.S.; Mao, D.R. Fate of fertilizer nitrogen for winter wheat/summer maize rotation in North China Plain under optimization of irrigation and fertilization. J. Nucl. Agric. Sci. 2009, 23, 334-340. (In Chinese)

55. Jin, X.X.; Zhang, X.Y.; Chen, S.Y.; Sun, H.Y.; Wang, Y.M.; Shao, L.W.; Gao, L.N. Effect of Different Irrigation Frequency and Amount on Nitrogen Uptake, Translocation of Winter Wheat. Acta Agric. Boreali-Sin. 2009, 24, 112-118. (In Chinese)

56. Scharf, P.C.; Alley, M.M. Residual Soil Nitrogen in Humid Region Wheat Production. J. Prod. Agric. 1994, 7 , 81-85. [CrossRef]

57. Olson, R.A.; Frank, K.D.; Diebert, E.J.; Drier, A.F.; Sander, D.H.; Johnson, V.A. Impact of Residual Mineral N in Soil on Grain Protein Yields of Winter Wheat and Con. Agron. J. 1976, 68, 769-772. [CrossRef] 
58. Zhao, J.Y.; Yu, Z.W. Effects of nitrogen rate on nitrogen fertilizer use of winter wheat and content of soil nitrate-N under different fertility condition. Acta Ecol. Sin. 2006, 26, 815-822. (In Chinese)

59. Chen, X.P.; Cui, Z.L.; Vitousek, P.M.; Cassman, K.G.; Matson, P.A.; Bai, J.S.; Meng, Q.F.; Hou, P.; Yue, S.C.; Romheld, V.; et al. Integrated soil-crop system management for food security. Proc. Natl. Acad. Sci. USA 2011, 108, 6399-6404. [CrossRef] [PubMed]

60. Zhou, S.L.; Zhang, F.S.; Wang, X.P. Studies on the spatio-temporal variations of soil $\mathrm{NO}_{3}-\mathrm{N}$ and apparent budget of soil nitrogen. I. Winter wheat. Acta Ecol. Sin. 2001, 21, 1782-1789. (In Chinese)

(C) 2020 by the authors. Licensee MDPI, Basel, Switzerland. This article is an open access article distributed under the terms and conditions of the Creative Commons Attribution (CC BY) license (http://creativecommons.org/licenses/by/4.0/). 